\title{
EFFECTS OF GENETICS AND ENVIRONMENT ON ISOFLAVONE CONTENT OF SOYBEAN FROM DIFFERENT REGIONS OF BRAZIL1
}

\author{
MERCEDES CONCÓRDIA CARRÃO-PANIZZI ${ }^{2}$, ADELAIDE DEL PINO BELÉIA ${ }^{3}$, KEISUKE KITAMURA ${ }^{4}$ \\ and MARIA CRISTINA NEVES OLIVEIRA ${ }^{5}$
}

\begin{abstract}
The effects of genetics and environmental factors on isoflavone content of soybean (Glycine max L.) cultivars grown in different locations in Brazil in 1993/94 were evaluated. Seeds of different cultivars were analised by high performance liquid chromatography (HPLC). In Rio Grande do Sul (RS), Paraná (PR), and Mato Grosso do Sul (MS) States, a significant difference in the isoflavone total content average of the cultivars IAS 5 and FT-Abyara $(163.9,116.4$ and $79.5 \mathrm{mg} / 100 \mathrm{~g}$, respectively) was observed. In general, IAS 5 contained higher isoflavone than FT-Abyara. Cultivars IAS 5 and FT-Abyara grown at Vacaria, $\mathrm{RS}\left(28^{\circ} 30^{\prime} \mathrm{S}\right.$ latitude $)$ with temperature average of $19^{\circ} \mathrm{C}$, had the highest isoflavone concentrations ( 218.7 and $163.8 \mathrm{mg} / 100 \mathrm{~g}$, respectively). In Palotina, PR (24²7' S latitude), where temperature average was $24^{\circ} \mathrm{C}$, the isoflavone concentrations were 105.9 and $86.8 \mathrm{mg} / 100 \mathrm{~g}$, respectively. The lowest isoflavone contents were observed for FT-Estrela and FT-Cristalina, (27.6 and $46.5 \mathrm{mg} / 100 \mathrm{~g}$, repectively) at Rondonópolis, MT (16 ${ }^{\circ} 20^{\prime} \mathrm{S}$ latitude), where the temperature was $27^{\circ} \mathrm{C}$.
\end{abstract}

Index terms: Glycine max, daidzin, genistin, crop location, HPLC

\section{EFEITOS DA GENÉTICA E DO AMBIENTE NOS TEORES DE ISOFLAVONÓIDES EM SOJA DE DIFERENTES REGIÕES DO BRASIL}

\begin{abstract}
RESUMO - Analisaram-se os efeitos da genética e de fatores ambientais nos teores de isoflavonóides em cultivares de soja (Glycine max L.) provenientes de diferentes locais do Brasil, na safra 1993/94. Sementes de diferentes cultivares foram analisadas por cromatografia líquida de alto desempenho (HPLC). Nos estados do Rio Grande do Sul (RS), Paraná (PR) e Mato Grosso do Sul (MS) observou-se diferença significativa entre as médias do conteúdo total de isoflavonóides das cultivares IAS 5 e FT-Abyara $(163,9,116,4$ e 79,5 mg/100 g, respectivamente). Em geral, IAS 5 apresentou teores mais altos de isoflavonóides que FT-Abyara. As cultivares IAS 5 e FT-Abyara provenientes de Vacaria, RS ( $28^{\circ} 30^{\prime}$ latitude S), com temperatura média de $19^{\circ} \mathrm{C}$, apresentaram concentrações mais altas de isoflavonóides (218,7 e 163,8 mg/100 g, respectivamente). Em Palotina, PR (24²7' latitude S) onde a temperatura média foi de $24^{\circ} \mathrm{C}$, as concentrações de isoflavonóides foram de 105,9 e 86,8 mg/100 g, respectivamente. Os menores teores de isoflavonóides foram observados nas cultivares FT-Estrela e FT-Cristalina (27,6 e 46,5 mg/100 g, respectivamente), em Rondonópolis, MT (16 20 latitude S), onde a temperatura foi de $27^{\circ} \mathrm{C}$
\end{abstract}

Termos para indexação: Glycine max, daidzina, genistina, locais de cultivo, HPLC

1 Accepted for publication on October 29, 1998.

2 Agronomist, Dr., Embrapa-Centro Nacional de Pesquisa de Soja (CNPSo), Caixa Postal 231, CEP 86001-970 Londrina, PR, Brazil. E-mail: mercedes@cnpso.embrapa.br

3 Agronomist, Ph.D., Dep. de Tecnologia de Alimentos e Medicamentos, Universidade Estadual de Londrina, CEP 86051-970 Londrina, PR, Brazil

${ }^{4}$ Biochemistry, Ph.D., Agriculture, Forestry and Fisheries Research Council's Secretariat, Ministry of Agriculture, Forestry and Fisheries. Kasumigaseki 1-2-1, Chyoda-Ku, Tokyo 100, Japan

${ }^{5}$ Mathematic, M.Sc., Embrapa-CNPSo.

\section{INTRODUCTION}

Potential health benefits of soy foods in the prevention and treatment of heart diseases and cancer warrant an increase in soybean consumption in the Western countries (Messina et al., 1994). Epidemiological data suggest that the low incidence of breast cancer in the Asian populations is related to their traditional diet, in which the soybean is an important component (Adlercreutz et al., 1991; Coward et al., 1993). The urinary excretion of 
isoflavones was highly correlated with soybean products intake (Adlercreutz et al., 1991). Anticancer effects of isoflavones place particular emphasis on soybean which is a good source of these compounds (Messina, 1995).

Isoflavones were found in soybean in the conjugated glucosides forms daidzin, genistin, and glycitin, their corresponding aglycones daidzein, genistein, and glycitein, and the malonyl glucosides: 6"-O-malonyl daidzin, 6"-O-malonyl genistin, and 6"-O-malonyl glycitin (Walter, 1941; Naim et al., 1973; Ohta et al., 1979, 1980; Kudou et al., 1991).

Kudou et al. (1991) reported that in soybean seeds, the total isoflavone content in the hypocotyl was 5.5 to 6.0 times higher than that of the cotyledons; the glycitin forms occurred only in the hypocotyl part and no isoflavones were observed in the seed coat. The accumulation of isoflavones occurred during seed filling (between 35 and 60 days after flowering), with genistin and malonyl genistin content increasing at the end of the seed development stage, while daidzin and malonyl daidzin increased during the entire period.

Variability on isoflavone concentration was observed among soybean cultivars grown in different locations and crop years (Eldridge \& Kwolek, 1983; Wang \& Murphy, 1994). Early maturing soybean cultivars, the so-called "summer-type soybeans", had a stable low concentration of isoflavones (Kitamura et al., 1991). High temperature during the seed filling stage was related as a major factor in determining the levels of isoflavones in seeds (Tsukamoto et al., 1995). Differences in isoflavone content were also observed among Brazilian soybean cultivars (Carrão-Panizzi \& Kitamura, 1995; Carrão-Panizzi, 1996).

The objective of this study was to evaluate the effects of genetic and crop location on isoflavone content in Brazilian soybean cultivars, which are grown in different environments, from Equator to $32^{\circ} \mathrm{S}$ latitude.

\section{MATERIAL AND METHODS}

Seed samples were collected from the 1993/94 final yield soybean trials, from different locations of Brazilian soybean production regions. The three states considered in the first experiment with 14 different locations were the following: Rio Grande do Sul (RS): Vacaria, Pelotas, Cruz Alta, Passo Fundo, Santa Rosa; Paraná (PR): Londrina, Ponta Grossa, Mariópolis, Palotina, Cascavel, Campo Mourão; and Mato Grosso do Sul (MS): Campo Grande, São Gabriel do Oeste, Sidrolândia. In these states, the effects of genetic and environmental factors on isoflavone content were evaluated in seeds of cultivars IAS 5 and FT-Abyara. Since within each state, different locations and number of locations were considered, the experiment was analysed as a complete randomized block design with hierarchical classification. Cultivar EMBRAPA 4 was evaluated just for conditions of Paraná State sowed in Londrina, Ponta Grossa, Mariópolis, Palotina, Cascavel, and Campo Mourão.

The second experiment was arranged in the same experimental design and the following states and locations were considered: Mato Grosso do Sul (MS): Campo Grande, São Gabriel do Oeste, Sidrolândia; Minas Gerais (MG): São Gotardo, Conceição das Alagoas; and Goiás (GO): Goiânia, Rio Verde. The cultivars FT-Cristalina and FT-Estrela were used in this experiment.

For both experiments the mathematical model is of mixed effects and the values for F-test were calculated according to Hicks (1973) methodology.

$\mathrm{Y}_{\mathrm{ijkl}}=\mathrm{m}+\mathrm{S}_{\mathrm{i}}+\mathrm{L}_{\mathrm{j}(\mathrm{i})}+\mathrm{B}_{\mathrm{k}(\mathrm{ij})}+\mathrm{C}_{\mathrm{l}}+\mathrm{C} * \mathrm{~L}_{\mathrm{jl}(\mathrm{i})}+\mathrm{S}^{*} \mathrm{C}_{\mathrm{il}}+\mathrm{e}_{\mathrm{ijkl}}$ where, $\mathrm{Y}$ is the observations; $\mathrm{m}$ is the effect of mean; $\mathrm{S}_{\mathrm{i}}$ is the effect of state; $\mathrm{L}_{j(\mathrm{i})}$ is the effect of location $_{j}$ within state $_{i}$; $\mathrm{B}_{\mathrm{k}(\mathrm{ij})}$ is the effect of block $\mathrm{k}_{\mathrm{k}}$ within state $\mathrm{i}_{\mathrm{i}}$ and location $_{\mathrm{j}}$; $\mathrm{C}_{1}$ is the effect of cultivar $; \mathrm{C}^{*} \mathrm{~L}_{\mathrm{jl}(\mathrm{i})}$ is the effect of interaction between cultivar ${ }_{1}$ and location $_{j}$ within state $_{i} ; \mathrm{S}^{*} \mathrm{C}_{\mathrm{il}}$ is the effect of interaction between State $_{i}$ and cultivar ${ }_{1}$; and $\mathrm{e}_{\mathrm{ijkl}}$ is the residual effect with normal distribution $\mathrm{N} \sim\left(0, \sigma^{2}\right)$.

The third experiment was carried out at Maranhão State as a complete randomized block design with treatments arranged in factorial: two locations, three cultivars and three blocks. The locations were Balsas and Tasso Fragoso with cultivars BR-35 (Rio Balsas), EMBRAPA 9 (Bays), and EMGOPA 312 (Potiguar). The mathematical model for this experiment was the following:

$$
\mathrm{Y}_{\mathrm{ijk}}=\mathrm{m}+\mathrm{L}_{\mathrm{i}}+\mathrm{B}_{\mathrm{j}(\mathrm{i})}+\mathrm{C}_{\mathrm{k}}+\mathrm{C}^{*} \mathrm{~L}_{\mathrm{ik}}+\varepsilon_{\mathrm{ijk}}
$$

where, $\mathrm{Y}$ is the observations; $\mathrm{m}$ is the effect of mean; $\mathrm{L}_{\mathrm{i}}$ is the effect of location; $\mathrm{B}_{\mathrm{j}(\mathrm{i})}$ is the effect of block $\mathrm{j}_{\mathrm{j}}$ within location $_{i}, \mathrm{C}_{\mathrm{k}}$ is the effect of cultivar ${ }_{\mathrm{k}} ; \mathrm{C}^{*} \mathrm{~L}_{\mathrm{ik}}$ is the effect of interaction between cultivar $r_{k}$ and location $n_{i} ; \mathrm{e}_{\mathrm{ijk}}$ is the residual effect with normal distribution $\mathrm{N} \sim\left(0, \sigma^{2}\right)$.

The fourth experiment arranged in a complete randomized block design, considered cultivars FT-Cristalina and FT-Estrela, sowed in Rondonópolis at Mato Grosso State, according to the following model: $\mathrm{Y}_{\mathrm{ij}}=\mathrm{m}+\mathrm{C}_{\mathrm{i}}+\mathrm{B}_{\mathrm{j}}+\varepsilon_{\mathrm{ij}}$ 
where, $Y_{i j}$ is the observations; $m$ is the effect of mean; $C_{i}$ is the effect of cultivar $r_{i}, B_{j}$ is the effect of block $k_{j}$; $\varepsilon_{i j}$ is the residual effect with normal distribution $\mathrm{N} \sim\left(0, \sigma^{2}\right)$.

To enhance efficiency of the estimatives and precision of the significance of the F-test, the assumptions to validate the analysis of variance (ANOVA) were evaluated throughout the following exploratory methods: normal distribution (Shapiro \& Wilk, 1965), homogeneity of variance (Hartley, 1940; Burr \& Foster, 1972), and model additivity (Tukey, 1949). Differences among treatment mean values were determined by Tukey's test at $\mathrm{P} \leq 0.05$ (Cochran \& Cox, 1957). Statistical Analysis System (SAS, 1995), and Sistema de Análise Estatística - SANEST (Zonta et al., 1982) were used for data analysis.

Daily local temperature average during the soybean season (November 1993 to April 1994) was recorded in order to identify temperature differences among locations.

For the isoflavone analysis, $100 \mathrm{~g}$ samples of soybean seeds containing $11 \%$ to $13 \%$ moisture were taken; $30 \mathrm{~g}$ were weighted to form subsamples, with $5 \mathrm{~g}$ milled for 40 seconds in a vibrating sample mill (Heiko mod. TI-100). Since traditional soybean processing into food products does not separate seed parts (seed coat, hypocotyl, and cotyledon), the isoflavone analysis was performed on the whole seed.

The quantitative analysis of isoflavones was carried out by high performance liquid chromatography (HPLC) (Kitamura et al., 1991; Kudou et al., 1991). One hundred $\mathrm{mg}$ of milled samples were extracted with $4.0 \mathrm{~mL}$ of $70 \%$ aqueous ethanol containing $0.1 \%$ acetic acid, in screw-capped test tubes, for one hour, at room temperature. After centrifugation ( 4 minutes at $16,000 \mathrm{~g}$, at $4^{\circ} \mathrm{C}$ ), a $40 \mu \mathrm{L}$ aliquot of the supernatant was used for HPLC analysis. Analyses of isoflavones were performed in a Tosoh chromatograph model UV 8011, equipped with UV detector. The separation was carried out on a reversed phase ODS-C18 column (Tosoh Corp., Tokyo, Japan) TKS-gel ODS-80TM (i.d. 4.6 × $250 \mathrm{~mm}$ ).

Elution of isoflavones compounds was performed by a linear gradient system. The initial gradient system consisted of $20 \%$ acetonitrile and $80 \%$ of $0.1 \%$ acetic acid solution. After 30 minutes of elution, the proportion of $45 \%$ of acetonitrile and $55 \%$ of acetic acid solution was reached and all the isoflavones were detected. The solvent flow rate was $1.0 \mathrm{~mL} /$ minutes, and the UV absortion was measured at $260 \mathrm{~nm}$. Purified soybean isoflavones (daidzin and genistin) were used as standards (Kudou et al., 1991). Isoflavone contents were calculated as $\mathrm{mg} / 100 \mathrm{~g}$ soybean flour (Eldridge \& Kwolek, 1983; Kitamura et al., 1991). Total isoflavone content was the sum of isoflavone glucosides genistin, daidzin, malonyl daidzin and malonyl genistin, on wet weight basis

\section{RESULTS AND DISCUSSION}

In different locations of the states of Rio Grande do Sul, Paraná and Mato Grosso do Sul, cultivar IAS 5 was consistently different from cultivar FT-Abyara considering isoflavone content, which suggested that genetic plays a significant role on isoflavone accumulation (Table 1). Cultivar EMBRAPA 4, tested just for locations in Paraná State, showed the lowest levels of isoflavones $(58.1 \mathrm{mg} / 100 \mathrm{~g})$ compared to cultivars IAS $5(131.4 \mathrm{mg} / 100 \mathrm{~g})$ and FT-Abyara (101.5 mg/100 g).

In addition to genetic differences among cultivars, variation was also observed in isoflavone contents of seeds harvested in different locations (Table 1), indicating that the isoflavone content was strongly affected by environmental conditions. Results from analysis of variance (ANOVA) indicated significant F-test responses for the interactions between locations cultivar (Table 1). Location and crop year also affected isoflavone content (Eldridge \& Kwolek, 1983; Wang \& Murphy, 1994). At Rio Grande do Sul State (Table 1), the greatest differences for both cultivars, FT-Abyara and IAS 5 were observed between Vacaria (163.8 and $218.7 \mathrm{mg} / 100 \mathrm{~g}$, respectively) and Santa Rosa (123.7 and $126.9 \mathrm{mg} / 100 \mathrm{~g}$, respectively), where temperature average during the soybean growing season (November to April) were $19^{\circ} \mathrm{C}$ and $23^{\circ} \mathrm{C}$, respectively. The highest temperature average observed in Santa Rosa may have reduced the isoflavone content of the cultivars, fact also observed by Kitamura et al. (1991). In Kyushu, Japan, Tsukamoto et al. (1995) reported that cultivar Lee had isoflavone concentration 5.8 times higher $(142.3 \mathrm{mg} / 100 \mathrm{~g})$ when sowed in July (temperature average $21^{\circ} \mathrm{C}$ ) compared to that sowed in May $(24.6 \mathrm{mg} / 100 \mathrm{~g})$ when temperatures were $25.9^{\circ} \mathrm{C}$.

In Paraná State, the same trend as in Rio Grande do Sul State was observed (Table 1). Cultivars 
TABLE 1. Total isoflavone glucosides $(\mathrm{mg} / 100 \mathrm{~g}, \pm \mathrm{SD})$ in seeds of soybean cultivars IAS 5 and FT-Abyara, as a function of sowing location within the state in the $1993 / 94$ crop season $(n=3, C V=7.93 \%)^{1}$.

\begin{tabular}{|c|c|c|c|c|c|c|}
\hline \multirow[t]{2}{*}{ State } & \multirow[t]{2}{*}{ Location } & \multirow{2}{*}{$\begin{array}{l}\text { Latitude } \\
\text { South }\end{array}$} & \multirow{2}{*}{$\begin{array}{c}\text { Altitude } \\
\text { (m) }\end{array}$} & \multirow{2}{*}{$\begin{array}{c}\text { Temperature } \\
\left({ }^{\circ} \mathrm{C}\right)\end{array}$} & \multicolumn{2}{|c|}{ Isoflavones (mg/100 g) } \\
\hline & & & & & FT-Abyara & IAS 5 \\
\hline \multirow[t]{9}{*}{$\begin{array}{l}\text { Rio Grande } \\
\text { do Sul }\end{array}$} & Vacaria & $28^{\circ} 30^{\prime}$ & 971 & 19 & $\begin{array}{l}163.8 \mathrm{aB} \\
( \pm 16.2)\end{array}$ & $\begin{array}{l}218.7 \mathrm{aA} \\
( \pm 25.1)\end{array}$ \\
\hline & Passo Fundo & $28^{\circ} 17^{\prime}$ & 687 & 20 & $155.6 \mathrm{aB}$ & $196.0 \mathrm{bA}$ \\
\hline & & & & & $( \pm 10.3)$ & $( \pm 10.6)$ \\
\hline & Pelotas & $31^{\circ} 45^{\prime}$ & 17 & 21 & $162.9 \mathrm{aB}$ & $185.3 \mathrm{bA}$ \\
\hline & & & & & $( \pm 12.2)$ & $( \pm 4.3)$ \\
\hline & Cruz Alta & $28^{\circ} 38^{\prime}$ & 452 & 21 & $132.9 \mathrm{bB}$ & $173.7 \mathrm{cA}$ \\
\hline & & & & & $( \pm 16.2)$ & $( \pm 8.5)$ \\
\hline & Sta. Rosa & $27^{\circ} 53^{\prime}$ & 277 & 23 & $123.7 \mathrm{bA}$ & $126.9 \mathrm{dA}$ \\
\hline & & & & & $( \pm 7.3)$ & $( \pm 8.3)$ \\
\hline Mean & & & & & $\begin{array}{c}147.8 \mathrm{aB} \\
( \pm 19.6)\end{array}$ & $\begin{array}{c}180.1 \mathrm{aA} \\
( \pm 28.4) \\
\end{array}$ \\
\hline \multirow[t]{11}{*}{ Paraná } & Mariópolis & $26^{\circ} 21^{\prime}$ & 800 & 20 & $\begin{array}{l}130.4 \mathrm{aA} \\
( \pm 10.5)\end{array}$ & $\begin{array}{l}\text { 145.1aA } \\
( \pm 9.7)\end{array}$ \\
\hline & Ponta Grossa & $25^{\circ} 05^{\prime}$ & 975 & 21 & $116.7 \mathrm{abB}$ & $143.4 \mathrm{aA}$ \\
\hline & & & & & $( \pm 13.6)$ & $( \pm 2.4)$ \\
\hline & Cascavel & $24^{\circ} 58^{\prime}$ & 800 & 22 & $102.9 \mathrm{bcB}$ & $136.5 \mathrm{aA}$ \\
\hline & & & & & $( \pm 2.7)$ & $( \pm 18.4)$ \\
\hline & Londrina & $23^{\circ} 11^{\prime}$ & 585 & 23 & $86.3 \mathrm{~dB}$ & $142.6 \mathrm{aA}$ \\
\hline & & & & & $( \pm 6.2)$ & $( \pm 17.1)$ \\
\hline & Campo Mourão & $24^{\circ} 02$ & 630 & 22 & $85.8 \mathrm{~dB}$ & $115.0 \mathrm{bA}$ \\
\hline & & & & & $( \pm 7.3)$ & $( \pm 6.3)$ \\
\hline & Palotina & $24^{\circ} 27$ & 376 & 24 & $86.8 \mathrm{cdB}$ & $105.9 \mathrm{bA}$ \\
\hline & & & & & $( \pm 6.1)$ & $( \pm 13.6)$ \\
\hline Mean & & & & & $\begin{array}{l}\text { 101.5bB } \\
\left( \pm_{19.0)}\right.\end{array}$ & $\begin{array}{l}\text { 131.4bA } \\
( \pm 19.0)\end{array}$ \\
\hline \multirow[t]{5}{*}{$\begin{array}{l}\text { Mato Grosso } \\
\text { do Sul }\end{array}$} & Campo Grande & $20^{\circ} 28^{\prime}$ & 532 & 25 & $\begin{array}{l}96.3 \mathrm{aA} \\
( \pm 4.5)\end{array}$ & $\begin{array}{l}93.2 \mathrm{aA} \\
( \pm 3.7)\end{array}$ \\
\hline & S. Gabr. Oeste & $19^{\circ} 21^{\prime}$ & 658 & - & $55.5 \mathrm{bB}$ & $93.8 \mathrm{aA}$ \\
\hline & & & & & $( \pm 2.6)$ & $( \pm 8.0)$ \\
\hline & Sidrolândia & $20^{\circ} 56^{\prime}$ & 484 & - & $68.5 \mathrm{bA}$ & $69.6 \mathrm{bA}$ \\
\hline & & & & & $( \pm 5.1)$ & $( \pm 9.5)$ \\
\hline Mean & & & & & $\begin{aligned} & 73.5 \mathrm{cB} \\
&( \pm 18.4)\end{aligned}$ & $\begin{aligned} & 85.5 \mathrm{cA} \\
&\left({ }^{ \pm} \mathbf{1 3 . 5}\right)\end{aligned}$ \\
\hline
\end{tabular}

1 Values of the interaction between location and cultivar, fixed within the state, followed by the same small letters in the columns and capital letters in the lines, are not significantly different (Tukey $\mathrm{P} \leq 0.05$ ); values from the interaction between state and cultivar, in bolding, followed by the same small letters in the columns and capital letters in the lines are not significantly different (Tukey $\mathrm{P} \leq 0.05$ ). 
IAS 5 and FT-Abyara presented higher isoflavone content in Mariópolis and in Ponta Grossa than in Palotina, which could be due to the local temperature average of $20^{\circ} \mathrm{C}, 21^{\circ} \mathrm{C}$ and $24^{\circ} \mathrm{C}$, respectively (Table 1). Mariópolis and Ponta Grossa are located at higher altitude $(800 \mathrm{~m}$ and $975 \mathrm{~m}$, respectively) than Palotina $(376 \mathrm{~m})$. Exactly the same trend observed for IAS 5 e FT-Abyara was also found for cultivar EMBRAPA 4, which isoflavone concentration was $74.6 \mathrm{mg} / 100 \mathrm{~g}$ in Mariópolis and $48.8 \mathrm{mg} / 100 \mathrm{~g}$ in Palotina.

At Londrina (PR), although the high temperature average of $23^{\circ} \mathrm{C}$, the cultivar IAS 5 presented a high isoflavone concentration (142.6 mg/100 g), compared to the concentrations observed in Mariópolis and Ponta Grossa, where temperature average was lower $\left(20^{\circ} \mathrm{C}\right)$ (Table 1$)$. Cultivar EMBRAPA 4 showed a similar response. According to Koeppen climate classification (Strahler, 1975), Londrina (23ำ1'50" S latitude; 585 m altitude) presents a subtropical climate with hot summer and high precipitation. Despite this classification, Londrina is located in a transition zone between temperate and subtropical regions, which confers to Londrina's climate an unstable behavior, ranging from temperate to subtropical. Therefore, results observed in Londrina for isoflavone contents were probably influenced by this climate variation. During seed filling, IAS 5 and EMBRAPA 4, which are early maturing cultivars, could be exposed to temperature variations that could occur in Londrina and were not detected. Cultivar FT-Abyara (intermediate maturing) had similar isoflavone concentration at Londrina $(86.3 \mathrm{mg} / 100 \mathrm{~g})$ and at Palotina ( $86.8 \mathrm{mg} / 100 \mathrm{~g}$ ) (Table 1$)$, as expected since both locations have similar high temperatures.

No differences in isoflavone content were observed between cultivars IAS 5 e FT-Abyara grown at Campo Grande and Sidrolândia, both located in Mato Grosso do Sul State. At São Gabriel do Oeste, however, the difference was significant (Table 1). Cultivar FT-Abyara was greatly influenced by sowing location, while IAS 5 showed this effect only in Sidrolândia (Table 1). In Mato Grosso do Sul State high temperatures are very common. This situation could have reduced isoflavone content of the cultivars, that showed similar concentrations to those observed in Palotina (PR), where local temperatures were also high (Table 1).

In general, isoflavone content was lower as latitude decreased (Table 1). Although Santa Rosa is located at higher latitude $\left(27^{\circ} 53^{\prime} \mathrm{S}\right)$, the local altitude is low $(277 \mathrm{~m})$, which increases local temperature average $\left(23^{\circ} \mathrm{C}\right)$. These conditions reduced isoflavone content of the cultivars compared with other locations of Rio Grande do Sul State (Table 1). In Mariópolis (PR), soybean cultivars contained high isoflavone content as a result of lower local temperature average and higher latitude among the locations in the State of Paraná, as well as seeds from locations at Mato Grosso do Sul State contained low average concentrations of isoflavones as a result of low latitude and high temperature average (Table 1).

A significant $(\mathrm{P} \leq 0.05)$ effect of location was observed for total isoflavone content of the cultivar IAS 5 and FT-Abyara in the States of Rio Grande do Sul, Paraná, and Mato Grosso do Sul (Table 1). The interaction between states and cultivars was significant $(\mathrm{P} \leq 0.05)$ (Table 1). Cultivar IAS 5 had the highest average levels of total isoflavones in all states. Both cultivars IAS 5 and FT-Abyara had isoflavone contents in decreasing order in the States of Rio Grande do Sul, Paraná, and Mato Grosso do Sul (Table 1). American and Japanese cultivars also exhibited genetic variations and effects of sowing location and year (Wang \& Murphy, 1994).

Differences for concentrations of daidzin, genistin, malonyl daidzin, and malonyl genistin were similar (Table 2) to differences observed for total isoflavones in the states of Rio Grande do Sul, Paraná and Mato Grosso do Sul (Table 1). The highest concentrations of these compounds were always observed in Rio Grande do Sul (Table 2). Cultivar IAS 5 had higher concentration of genistin and malonyl genistin than cultivar FT-Abyara suggesting that IAS 5 would be suitable to produce genistein when properly processed. Genistein, a compound formed by hydrolysis of the glucoside genistin (Matsuura et al., 1989), has properties similar to the antiestrogen drug tamoxifen, which is used in breast cancer therapy (Peterson \& Barnes, 1991). Indeed, anticancer activity of genistein in cancers of prostata (Peterson \& Barnes, 1993) and colon (Steele et al., 
1995), as well as in vitro angiogenesis (Fotsis et al., 1993 ) has been reported. Information about isoflavone compounds distribution in Brazilian soybean cultivars is important because isoflavone glucosides are the substrate of the enzime $\beta$-glucosidase that forms the aglucone genistein and daidzein which are potential substances in preventing cancer. The aglycones genistein and daidzein are also related to astringency observed in the soybean flavor (Matsuura et al., 1989; Okubo et al., 1992).

The total isoflavone concentration average of cultivars FT-Estrela and FT-Cristalina were the same in Goiás and Minas Gerais (Table 3). The interaction between cultivar and state was significant $(\mathrm{P} \leq 0.05)$. FT-Estrela contained higher total isoflavones than cultivars FT-Cristalina in all states, except for Mato Grosso do Sul (Table 3). In Mato Grosso do Sul there was a significant reduction of average levels of these compounds for both cultivars (Table 3 ).

Sowing location within each state affected isoflavone content of cultivars FT-Estrela and FT-Cristalina (Table 3). Clear evidence of the effects of temperature on isoflavone concentrations was observed in Minas Gerais State. Isoflavone content was lower at Conceição das Alagoas $(53.0 \mathrm{mg} / 100 \mathrm{~g})$ than at São Gotardo $(94.5 \mathrm{mg} / 100 \mathrm{~g})$ as a consequence of temperature average of both locations $\left(26^{\circ} \mathrm{C}\right.$ and $23^{\circ} \mathrm{C}$, respectively) (Table 3 ). $1,055 \mathrm{~m}$ of altitute at São Gotardo explains the reduced local temperature average despite the same latitude for both locations (Table 3).

In Rondonópolis, Mato Grosso State $\left(16^{\circ} 28^{\prime} \mathrm{S}\right.$ latitude, $230 \mathrm{~m}$ altitude, and local temperature average of $27^{\circ} \mathrm{C}$ ), the isoflavone content in cultivars FT-Estrela and FT-Cristalina was very reduced, 27.6 and $46.5 \mathrm{mg} / 100 \mathrm{~g}$, respectively. These results support the idea that temperature during seed development is one of the major factors that have influence the total seed isoflavone content as also observed by Tsukamoto et al. (1995).

At Maranhão State, in Balsas and Tasso Fragoso, both located at low latitude, the isoflavone contents of the cultivars BR-35, EMBRAPA 9 (Bays) and $\mathrm{BR} / \mathrm{EMGOPA} 312$ were very reduced as a result of the high temperatures of this tropical region (Table 4). Results from analysis of variance (ANOVA), indicated a significative interaction between local cultivar.

TABLE 2. Average ( \pm SD) concentration of daidzin, genistin, malonyl daidzin and malonyl genistin $(\mathrm{mg} / 100 \mathrm{~g})$ in seeds of soybean cultivars sowed in different states in the 1993/94 crop season ${ }^{1}$.

\begin{tabular}{|c|c|c|c|c|c|c|}
\hline \multirow[t]{2}{*}{ State } & \multicolumn{3}{|c|}{ Cultivar } & \multicolumn{3}{|c|}{ Cultivar } \\
\hline & IAS 5 & FT-Abyara & Mean & IAS 5 & FT-Abyara & Mean \\
\hline & \multicolumn{3}{|c|}{ Daidzin } & \multicolumn{3}{|c|}{ Genistin } \\
\hline Rio Grande do Sul & $\begin{array}{l}11.9 \mathrm{aA} \\
( \pm 2.2)\end{array}$ & $\begin{array}{l}11.4 \mathrm{aA} \\
( \pm 1.5)\end{array}$ & $\begin{array}{c}11.7 \mathrm{a} \\
( \pm 1.8)\end{array}$ & $\begin{array}{l}23.6 \mathrm{aA} \\
( \pm 1.5)\end{array}$ & $\begin{array}{l}17.4 \mathrm{aB} \\
( \pm 2.0)\end{array}$ & $\begin{array}{r}20.5 \mathrm{a} \\
( \pm 0.6)\end{array}$ \\
\hline Paraná & $\begin{array}{l}9.6 \mathrm{bA} \\
( \pm 1.9)\end{array}$ & $\begin{array}{l}8.9 \mathrm{bA} \\
( \pm 1.4)\end{array}$ & $\begin{array}{r}9.2 \mathrm{~b} \\
( \pm 1.6)\end{array}$ & $\begin{array}{l}19.7 \mathrm{bA} \\
( \pm 2.3)\end{array}$ & $\begin{array}{l}12.4 \mathrm{bB} \\
( \pm 3.6)\end{array}$ & $\begin{array}{r}16.9 \mathrm{~b} \\
( \pm 2.9)\end{array}$ \\
\hline Mato Grosso Sul & $\begin{array}{l}6.6 \mathrm{cB} \\
( \pm 0.8)\end{array}$ & $\begin{array}{r}8.1 \mathrm{bA} \\
( \pm 1.7)\end{array}$ & $\begin{array}{r}7.3 \mathrm{c} \\
( \pm 1.6)\end{array}$ & $\begin{array}{l}15.2 \mathrm{cA} \\
( \pm 2.6)\end{array}$ & $\begin{array}{l}10.9 \mathrm{cB} \\
( \pm 1.5)\end{array}$ & $\begin{array}{r}13.0 \mathrm{c} \\
( \pm 3.3)\end{array}$ \\
\hline \multirow[t]{2}{*}{$\mathrm{CV}(\%)$} & \multicolumn{3}{|c|}{12.97} & \multicolumn{3}{|c|}{10.49} \\
\hline & \multicolumn{3}{|c|}{ Malonyl daidzin } & \multicolumn{3}{|c|}{ Malonyl genistin } \\
\hline Rio Grande do Sul & $\begin{array}{l}39.7 \mathrm{aB} \\
( \pm 9.4)\end{array}$ & $\begin{array}{l}42.6 \mathrm{aA} \\
( \pm 6.3)\end{array}$ & $\begin{array}{c}41.1 \mathrm{a} \\
( \pm 9.6)\end{array}$ & $\begin{array}{l}104.9 \mathrm{aA} \\
( \pm 7.4)\end{array}$ & $\begin{array}{l}76.4 \mathrm{aB} \\
( \pm 8.3)\end{array}$ & $\begin{array}{r}90.6 a \\
( \pm 26.3)\end{array}$ \\
\hline Paraná & $\begin{array}{l}28.9 \mathrm{bB} \\
( \pm 3.5)\end{array}$ & $\begin{array}{l}29.6 \mathrm{bB} \\
( \pm 4.7)\end{array}$ & $\begin{array}{c}29.3 \mathrm{~b} \\
( \pm 5.0)\end{array}$ & $\begin{array}{r}73.2 \mathrm{bA} \\
( \pm 17.46)\end{array}$ & $\begin{array}{l}50.6 \mathrm{bB} \\
( \pm 12.1)\end{array}$ & $\begin{array}{r}62.0 \mathrm{~b} \\
( \pm 17.3)\end{array}$ \\
\hline Mato Grosso Sul & $\begin{array}{l}18.0 \mathrm{cB} \\
( \pm 3.3)\end{array}$ & $\begin{array}{l}20.7 \mathrm{cA} \\
( \pm 6.2)\end{array}$ & $\begin{array}{l}19.3 \mathrm{c} \\
( \pm 3.5)\end{array}$ & $\begin{array}{l}45.8 \mathrm{cA} \\
( \pm 7.4)\end{array}$ & $\begin{array}{l}33.7 \mathrm{cB} \\
( \pm 10.5)\end{array}$ & $\begin{array}{r}39.8 \mathrm{c} \\
( \pm 9.3)\end{array}$ \\
\hline $\mathrm{CV}(\%)$ & \multicolumn{3}{|c|}{9.16} & \multicolumn{3}{|c|}{7.47} \\
\hline
\end{tabular}


TABLE 3. Average $( \pm \mathrm{SD})$ concentration of total isoflavone glucosides $(\mathrm{mg} / 100 \mathrm{~g})$ in seeds of soybean cultivars FT-Estrela and FT-Cristalina as a function of interaction between sowing location within the state and cultivar in the $1993 / 94$ crop season $(n=3, C V=10.08 \%)^{1}$.

\begin{tabular}{|c|c|c|c|c|c|c|}
\hline \multirow[t]{2}{*}{ State } & \multirow[t]{2}{*}{ Location } & \multirow{2}{*}{$\begin{array}{c}\text { Latitude } \\
\text { South }\end{array}$} & \multirow{2}{*}{$\begin{array}{c}\text { Altitude } \\
(\mathrm{m})\end{array}$} & \multirow{2}{*}{$\begin{array}{c}\text { Temperature } \\
\left({ }^{\circ} \mathrm{C}\right) \\
\end{array}$} & \multicolumn{2}{|c|}{ Isoflavones (mg/100 g) } \\
\hline & & & & & FT-Estrela & FT-Cristalina \\
\hline \multirow[t]{3}{*}{ Goiás } & Goiânia & $16^{\circ} 40^{\prime}$ & 749 & 23 & $\begin{array}{l}67.1 \mathrm{bA} \\
( \pm 9.4)\end{array}$ & $\begin{array}{l}55.4 \mathrm{bB} \\
( \pm 3.4)\end{array}$ \\
\hline & Rio Verde & $17^{\circ} 26^{\prime}$ & 715 & - & $112.7 \mathrm{aA}$ & $70.2 \mathrm{aB}$ \\
\hline & & & & & $( \pm 5.3)$ & $( \pm 4.1)$ \\
\hline Mean & & & & & $\begin{array}{l}89.9 \mathrm{aA} \\
\left({ }^{ \pm 8.9)}\right.\end{array}$ & $\begin{array}{l}62.8 \mathrm{bB} \\
( \pm 25.7)\end{array}$ \\
\hline \multirow[t]{2}{*}{ Minas Gerais } & C. Alagoas & $19^{\circ} 55^{\prime}$ & 509 & 26 & $\begin{array}{l}61.7 \mathrm{bA} \\
( \pm 7.8)\end{array}$ & $\begin{array}{r}44.3 \mathrm{bB} \\
( \pm 10.3)\end{array}$ \\
\hline & São Gotardo & $19^{\circ} 20^{\prime}$ & 1055 & 23 & $\begin{array}{l}90.8 \mathrm{aA} \\
( \pm 1.8) \\
\end{array}$ & $\begin{array}{l}98.3 \mathrm{aA} \\
( \pm 0.3) \\
\end{array}$ \\
\hline Mean & & & & & $\begin{array}{l}76.2 \mathrm{bA} \\
( \pm 30.3)\end{array}$ & $\begin{array}{r}71.3 \mathrm{aA} \\
( \pm 16.7)\end{array}$ \\
\hline \multirow[t]{3}{*}{$\begin{array}{l}\text { Mato Grosso } \\
\text { do Sul }\end{array}$} & Campo Grande & $20^{\circ} 28^{\prime}$ & 532 & 25 & $\begin{array}{l}91.0 \mathrm{aA} \\
( \pm 5.5)\end{array}$ & $\begin{array}{l}43.2 \mathrm{bB} \\
( \pm 2.3)\end{array}$ \\
\hline & S. G. Oeste & $19^{\circ} 21^{\prime}$ & 658 & - & $\begin{array}{l}49.0 \mathrm{bA} \\
( \pm 1.4)\end{array}$ & $\begin{array}{l}56.3 \mathrm{aA} \\
( \pm 3.5)\end{array}$ \\
\hline & Sidrolândia & $20^{\circ} 56^{\prime}$ & 484 & - & $\begin{array}{r}45.7 \mathrm{bA} \\
( \pm 14.3) \\
\end{array}$ & $\begin{array}{l}42.6 \mathrm{bA} \\
( \pm 5.5) \\
\end{array}$ \\
\hline Mean & & & & & $\begin{array}{l}61.9 \mathrm{cA} \\
( \pm 2.8)\end{array}$ & $\begin{aligned} & 47.4 \mathrm{cB} \\
&( \pm 23.2)\end{aligned}$ \\
\hline
\end{tabular}

TABLE 4. Average $( \pm \mathrm{SD})$ concentration of total isoflavone glucosides $(\mathrm{mg} / 100 \mathrm{~g})$ in seeds of soybean cultivars as a function of the interaction between sowing location and cultivar at the State of Maranhão, in the 1993/94 crop season $(n=3, C V=10.86 \%)^{1}$.

\begin{tabular}{lcccccc}
\hline Location & Latitude & Altitude & \multicolumn{4}{c}{ Isoflavones (mg/100 g) } \\
\cline { 4 - 7 } & South & $(\mathrm{m})$ & BR-35 & EMBRAPA 9 (Bays) & BR/EMGOPA 312 & Mean \\
\hline \multirow{2}{*}{ Balsas } & $07^{\circ} 27^{\prime}$ & 250 & $43.3 \mathrm{aA}$ & $34.7 \mathrm{aB}$ & $52.2 \mathrm{aA}$ & $43.4 \mathrm{a}$ \\
& & & $( \pm 5.9)$ & $( \pm 3.5)$ & $( \pm 6.1)$ & $( \pm 8.8)$ \\
Tasso Fragoso & $08^{\circ} 27^{\prime}$ & 242 & $46.4 \mathrm{aA}$ & $39.8 \mathrm{aA}$ & $37.5 \mathrm{bB}$ & $42.2 \mathrm{a}$ \\
& & & $( \pm 4.8)$ & $( \pm 1.0)$ & $( \pm 2.1)$ & $( \pm 4.8)$ \\
\hline
\end{tabular}

${ }^{1}$ Mean values followed by the same small letter in the columns and capital letter in the lines are not significantly different (Tukey P $\leq 0.05$ ). 
Our results demonstrate that isoflavone concentration is influenced by genetic and environmental factors. Thus breeding soybean cultivars for high or low isoflavone concentration is not an easy task. As observed in the literature, ingestion of foods with higher levels of these compounds could help in the treatment or prevention of breast and prostate cancer. In this case, Brazilian Southern states, where temperatures are cooler and concentrations of these compounds are higher, would be more suitable for soybean production aiming at using in medicine development. On the other hand, soybean cultivars with a reduced isoflavone concentration occur in locations of warmer temperatures (low latitudes). Hence, these locations could be suitable for production of soybean with better flavor since isoflavones are responsible for the astringency sensation observed in soybean products.

\section{CONCLUSIONS}

1. Isoflavone concentration in soybean cultivars is genetically determined and affected by environment factors.

2. Cultivar IAS 5 has higher isoflavone content than cultivar FT-Abyara in all locations of Mato Grosso do Sul, Rio Grande do Sul, and Paraná states.

3 . High local temperature average decreases isoflavone concentration of soybean cultivars.

4. Depending on sowing location it is possible to produce soybean for medicine uses or less astringent soybean products.

\section{ACKNOWLEDGEMENT}

To Drs. S.H. West, N. Neumaier, and A.R. Panizzi for reading early drafts of the manuscript; to Drs. N.E. Arantes, R.B. Rolim, P.F. Bertagnolli, N.L. Zuffo, A. Harara and M.C. Meyer for provinding the soybean seeds; to Brazilian Research Council (CNPq) and National Agriculture Research Center (NARC) for supporting this study.

\section{REFERENCES}

ADLERCREUTZ, H.; HONJO, H.; HIGASHI, A.; FOTSIS, T.; HAMALAINEN, E.; HASEGAWA, T.; OGAWA, H. Urinary excretion of lignans and isoflavonoid phytoestrogens in Japanese men and women consuming a traditional Japanese diet. American Journal of Clinical Nutrition, v.54, p.1093-1100, 1991

BURR, I.W.; FOSTER, L.A. A test for equality of variances. West Lafayette: Univ. of Purdue, 1972. 26p. (Mimeo series, 282)

CARRÃO-PANIZZI, M.C. Avaliação de cultivares de soja quanto aos teores de isoflavonóides. Pesquisa Agropecuária Brasileira, Brasília, v.31, n.10, p.691-698, out. 1996.

CARRÃO-PANIZZI, M.C.; KITAMURA, K. Isoflavone content in Brazilian soybean cultivars. Breeding Science, v.45, p.295-300, 1995.

COCHRAN, W.G.; COX, G.M. Experimental designs. New York: John Willey, 1957. 611p.

COWARD, L.; BARNES, N.C.; SETCHELL, K.D.R.; BARNES, S. Genistein, daidzein, and their $\beta$-glycoside conjugates: Antitumor isoflavones in soybean foods from American and Asian diets. Journal of Agricultural and Food Chemistry, v.41, p.1961-1967, 1993.

ELDRIDGE, A.; KWOLEK, W. Soybean isoflavones: Effect of environment and variety on composition. Journal of Agricultural and Food Chemistry, v.31, p.394-396, 1983.

FOTSIS, T.; PEPPER, M.; ADLERCREUTZ, H.; FLEISCHMANN, G.; HASE, T.; MONTESANO, R.; SCHWEIGERER, L. Genistein, a dietary-derived inhibitor of in vitro angiogenesis. Proceedings of the National Academy of Sciences of the United States of America: Serie Medical Sciences, v.90, p.2690-2694, 1993.

HARTLEY, H.O. Testing the homogeneity of a set of variances. Biometrika, v.31, p.249-255, 1940.

HICKS, C.R. Fundamental concepts in the design of experiments. 2.ed. New York: Holt, Rinehart and Winston, 1973. 349p

KITAMURA, K.; IGITA, K.; KIKUCHI, A.; KUDOU, $\mathrm{S}$; OKUBO, K. Low isoflavone content in early maturing cultivars, so called summer-type soybeans (Glycine $\max (\mathrm{L}$. ) Merrill). Japanese Journal of Breeding, v.41, p.651-654, 1991. 
KUDOU, S.; FLEURY, Y.; WELTI, D.; MAGNOLATO, D.; UCHIDA, T.; KITAMURA, K.; OKUBO, K. Malonyl isoflavone glycosides in soybean seeds (Glycine $\max ($ L.) Merrill). Agricultural and Biological Chemistry, v.55, p.2227-2233, 1991.

MATSUURA, M.; OBATA, A.; FUKUSHIMA, D Objectionable flavor of soymilk developed during the soaking of soybeans and its control. Journal of Food Science, v.54, p.602-605, 1989.

MESSINA, M. Modern applications for the ancient bean soybeans and the prevention and treatment of chronic disease. Journal of Nutrition, v. 125, p.567S-569S, 1995.

MESSINA, M.; MESSINA, V.; SETCHELL, K. The simple soybean and your health. Garden City Park: Avery, 1994. 260p

NAIM, M.; GESTETNER, B.; KIRSON, I.; BIRK, Y; BONDI, A. A new isoflavone from soybeans. Phytochemistry, v.12, p.169-170, 1973.

OHTA, N.; KUWATA, G.; AKAHORI, H.; WATANABE, T. Isoflavonoid constituents of soybeans and isolation of a new acetyldaidzin. Agricultural Biological Chemistry, v.43, p.1415-1419, 1979.

OHTA, N.; KUWATA, G.; AKAHORI, H.; WATANABE, $\mathrm{T}$. Isolation of new isoflavone acetyl glucoside 6"-O-acetylgenistin from soybeans. Agricultural Biological Chemistry, v.44, p.469-470, 1980

OKUBO, K.; IJIMA, M.; KOBAYASHI, Y.; YOSHIKOSHI, M.; UCHIDA, T.; KUDOU, S Components responsible for the undesirable taste of soybean seeds. Bioscience Biotechnology Biochemistry, v.56, p.99-103, 1992.

PETERSON, G.; BARNES, S. Genistein inhibition of the growth of human breast cancer-cells: independence from estrogen receptors and the multi-drug resistance gene. Biochemical and Biophysical Research Communication, v.179, p.661-667, 1991.

PETERSON, G.; BARNES, S. Genistein and biochanin A inhibit the growth of human prostate cancer cells but not epidermal growth factor receptor tyrosine autophosphorylation. The Prostate, v.22, p.335-345, 1993.

SAS INSTITUTE. SAS proprietary software release 6.09. Cary, NC, 1995.

SHAPIRO, S.S.; WILK, M.B. An analysis of variance test for normality. Biometrika, v.52, p.591-611, 1965

STEELE, V.E.; PEREIRA, M.A.; SIGMAN, C.C.; KELLOFF, G.J. Cancer chemoprevention agent development strategies for genistein. Journal of Nutrition, v.125, p.713S-716S, 1995.

STRAHLER, A.N. Classification of global climates. In STRAHLER, A.N. Physical geography. New York: John Wiley, 1975. p.243-245.

TSUKAMOTO, C.; SHIMADA, S.; IGITA, K.; KUDOU, S.; KOKUBUN, M.; OKUBO, K.; KITAMURA, K. Factors affecting isoflavone content in soybean seeds: changes in isoflavones, saponins, and composition of fatty acids at different temperatures during seed development. Journal of Agricultural and Food Chemistry, v.43, p.1184$1192,1995$.

TUKEY, J.W. One degree of freedom for non-additivity. Biometrics, v.5, p 232-242, 1949.

WALTER, E.D. Genistin (an isoflavone glucoside) and its aglucone, genistein, from soybeans. Journal of the American Chemistry Society, v.63, p.3273-3276, 1941.

WANG, H.; MURPHY, P. Isoflavone composition of American and Japanese soybeans in Iowa: Effects of variety, crop year, and location. Journal of Agricultural and Food Chemistry, v.42, p.1674-1677, 1994.

ZONTA, E.P.; MACHADO, A.A.; SILVEIRA JÚNIOR, P. Sistema de Análise Estatística- SANEST, Registro na SEI No 066060. Pelotas: UFPEL, 1982. 63p 